\title{
“(Re)canonizing world literature with digital archives and online magazines from Hong Kong, Taiwan, and Mainland China"1
}

\section{Jessica Siu-yin Yeung}

To cite this article: By Jessica Siu-yin Yeung (2019) “(Re)canonizing World Literature with Digital Archives and Online Magazines from Hong Kong, Taiwan, and Mainland China.” Humans at Work in the Digital Age: Forms of Digital Textual Labor. Ed. Andrew Pilsch and Shawna Ross. 223-38. London: Routledge, 2019.

David Damrosch calls for "engag[ing] more actively in interrelating old and new media and the methods of their analysis" in the "postliterary age," in which more literary works have been adapted into media forms. Comparing to Damrosch's way of addressing how the big-data trend shapes the development of literary studies by highlighting the adaptation of Dante's Inferno into a video game, ${ }^{2}$ Franco Moretti approaches the trend from a theoretical perspective by proposing "distant reading" and other techniques that adopt big-data analysis to map literary trends. ${ }^{3}$ In face of this digital turn in world literature, I argue that we can look at how creative work, rendition, and criticism are published and circulated in the digital space and, in turn, should scrutinize the digital labor involved in making this happen, thereby revealing problems and inequality in the canon formation of world literature. Specifically, this chapter probes the role of digital labor in canonizing Third-World literature with reference to four sets of digital archives and databases and two literary magazines from Hong Kong, Taiwan, and Mainland China. The launches of these archives and magazines have taken place starting in 2000. The archives, databases, and literary magazines I examine are the Hong Kong Literature Database (2000-2018) $)^{4}$ and its affiliated archive, Prof. Lu Wei-luan's Collection: Hong Kong Literature Archive (2005-2007), ${ }^{5}$ the Hong Kong English Literature Database (2010-), ${ }^{6}$ the Taiwan Literature Archives (2014-), ${ }^{7}$ Cha: An Asian Literary Journal (2007-2019), ${ }^{8}$ and the Paper Republic (2007-). ${ }^{9}$ I have chosen these particular resources for exploring the role of digital labor in canonizing or recanonizing Hong Kong, Taiwan, and Mainland Chinese literatures as world 
literatures because of their prevalence (their large user bases), scale (the number of texts they contain), and continued maintenance. Furthermore, these digital archives represent a diverse spectrum that includes, respectively, Hong Kong Chinese-language literature, Hong Kong anglophone literature, Taiwan literature, Asian literature, and Chinese literature in translation from the modern (1911-1949) and the contemporary period (1950-) at large.

\section{Asian digital humanities}

I approach questions of digital labor with an eagerness to democratize the traditionally academic study of literature through the internet to promote cross-cultural reading and understanding of local, national, or regional literatures. I am especially interested in whether these digital laborers have succeeded in elevating their local, national, or regional national literatures to the status of world literature. ${ }^{10}$ I test assumptions about "free labor" in the operation of the aforementioned archives, databases, and literary magazines. To explore the broader significance of digital labor for world literature, I attend to three problems in canon formationtranslation, the problematic notion of the "world," and various forms of "-centrisms." I argue that digital labor plays a pivotal role in the worlding mechanism of regional and national literatures in the East Asian context. Referring to Pierre Bourdieu's concepts of field, doxa, and capital, I conceive the East Asian digital literary field as an arena with its own set of practice and the players' internalization of such conventions, or doxa. As an integral practice in the field to accumulate social capital (literary networks), cultural capital (literati status), and symbolic capital (literary reputation) essential to sustaining the role of the agents or the players in the field, these agents (archivists and editors) perform digital labor through digital literary production. Such digital labor includes setting up literary archives, editing online literary magazines, and publishing literary translation in English to promote the regional and national literatures to a wider readership. This is because these agents assume that a major factor determining whether a particular body of Third-World literature can reach an international readership or enter the world literary canon is through literary translation or textual circulation. ${ }^{11}$

The doxa of the world literary field, however, has an underlying assumption of canonization: The source region of a body of literature should attain the status of a nation or a nation-state to enter the canon. ${ }^{12}$ This nationalistic doxa of the world literary field ${ }^{13}$ defies the 
digital labor (literary production) of the East Asian digital literary field, because places like Hong Kong and Taiwan are still remain a city or an island nation denied the status of a nation by the United Nations. ${ }^{14}$ The digital labor of these East Asian archivists and editors, however, is still productive in maintaining the agents in the field through rewarding the agents with various forms of capital. Such labor, moreover, slowly moves the positionality of these regional literatures into the world literary canon by engaging more readers, researchers, scholars, and teachers in the formation of theoretical concepts and critical discourse of canonization despite the nationcentered mechanism of the world literary field.

The case of digital labor in East Asia illuminates a broader predicament facing ThirdWorld literature, one related both to world literature and to the "free labor paradox"- a term I use to invoke ongoing scholarly debates about the nature and status of unpaid labor as "free labor." The free labor paradox is complicated by the hybrid nature of digital archives and literary magazines, which combine literary-critical approaches with library and information sciences (through the construction of an archive) and with popular culture (through the digital publication of popular magazines). Though the digital humanities are a new area of inquiry, the field has already begun to influence Asian Studies, as seen in Sun Sun Lim and Cheryll Ruth R. Soriano's edited volume ${ }^{15}$ and Stanford University's conference on Digital Humanities Asia. ${ }^{16}$ Lim and Soriano in particular suggest one of the major problems of East Asian digital labor - that each local or national effort of cultural production is still largely restricted to a local-level—which may be combatted through an inter-Asian approach:

Currently, different Asian countries fund research captured only in their native languages. Such nationally-defined and locally-focused research effectively resides in silos and fail to inform, influence or initiate meaningful comparative research. Instead, there should be a concerted effort to exploit digital communication platforms for intra-regional exchange of data and knowledge for greater cross-fertilization of ideas with a view towards more broadly grounded theorization. ${ }^{17}$

Their comparative perspective for developing a theoretical framework in Asian studies informs my approach to East Asian digital literary labor. Lim and Soriano point out that two hindrances to comparing digital cultures in the inter-Asian context are the funded "research captured only in 
their native languages" and the "nationally-defined and locally-focused research." This view on the lack of translation and absence of international perspective has commonly been seen as the crux that determines whether a regional literature can become world literature. Lawrence Venuti, however, argues that this is a misconception that ought to be rethought:

Translation patterns have created and consolidated the terms of cultural recognition for both hegemonic and certain developing countries, but without in any way diminishing the linguistic and cultural hierarchies in which those countries continue to be positioned. ${ }^{18}$

In other words, the fact that Third-World literature has to be translated into the English language in order to become world literature reveals the Eurocentric mechanism in world literature and how the Third-World countries compromise their nuances in their originals in order to venture on entering the canon. The "linguistic and cultural hierarchies" of Third-World literature and FirstWorld literature are further consolidated as the former circulates in the internet in the form of English rendition.

Third-World scholars, translators, and editors actively offer their digital labor to improve the circulation of their local, national, and regional literatures by taking part in the translation, publication, and distribution through the internet. Their labor results in digital products as the East Asian literary archives and online literary magazines. These digital products, however, remain under-examined because of their interdisciplinarity. ${ }^{19}$ Lim and Soriano's book on Asian media studies, for instance, covers a range of digital media products, from dating sites and emails to pop music and social media. Literary archives and online literary magazines that border the disciplines of Third-World literature, world literature, area studies, digital humanities, library science, and popular culture have thus far received little critical attention. Hence an objective of this chapter is to initiate the discussion on the significance of digital labor and the products of such labor in the context of East Asian digital archives and literary magazines by providing some primary data for further studies on this emerging field.

\section{The free labor paradox}

A key debate in defining digital labor concerns whether the unwaged and exploited labor-what I am designating "free labor"_ can be compensated by non-monetary rewards. 
Tiziana Terranova draws on Maurizio Lazzarato's idea of "immaterial labor"20 to conceive digital labor as a sum of free labor and immaterial labor. ${ }^{21}$ By "immaterial labor," Lazzarato refers to two aspects of labor: the "'information content' of the commodity [which] refers directly to the changes taking place in workers' labor processes" and the "“cultural content' of the commodity ..., the kinds of activities involved in defining and fixing cultural and artistic standards, fashions, tastes, consumer norms, and more strategically, public opinion." ${ }^{22}$ Terranova and Lazzarato are both discerning in their views on digital labor, especially if I conceive the continuous effort and unpaid work (free labor) devoted to maintaining the online literary magazine, Cha, which comprises information contents (stories, poems, reviews, renditions, and essays) and cultural content (region-themed issues, featured authors and poets, and promotion of poetry contests and writing workshop series).

Terranova's formula of digital labor as a sum of free labor and immaterial labor, nevertheless, is not applicable to the digital archives in this chapter. This is because the scholars who set up the archives have gained institutional and governmental support in the forms of research grants, so their labor is not free in an unpaid sense. For example, Elaine Yee-lin Ho, a former Professor in English at the University of Hong Kong, received a governmental research grant from the Research Grants Council of Hong Kong for founding and running the Hong Kong English Literature Database ${ }^{23}$ Kuei-fen Chiu, the Distinguished Professor and Director of the Research Center for the Humanities and Social Sciences at the National Chung Hsing University, has also gained the institutional support from the Ministry of Culture in Taiwan to work on "a multi-year "virtual museum' project" in which she is in charge of "constructing the digital timeline of Taiwan literary history" for the Taiwan Literature Archives. ${ }^{24}$ The cases of Ho and Chiu dismiss Terranova's claim about digital labor as being not "equivalent to employment" 25 because their cases show that digital labor can be conceived as a constituent of a digital archivist's employment, though not necessarily "equivalent to employment."26

The case of government-funded digital archives is different from that of the privately funded online literary magazines, which are founded to promote local (Taiwan and Hong Kong), national (Mainland China), and regional (Asian) literatures through publishing literary translation, encouraging the writing of creative works, and facilitating criticism and reviews of 
literary works and other forms of arts such as photography and film. The government-funded digital archives also differ from the privately funded online literary magazines as the former tend to place a stronger emphasis on literary and local history and have a less flexible format of contents (authorial indexing, genre-based categories, and bibliographic entries). While the archives are primarily designated to provide research materials for academics, the magazines cater to a more diverse readership to attract both academic and non-academic readers. These differences are most visibly seen in the Taiwan Literature Archives and Cha.

For unpaid translators, writers, and editors of online literary magazines, the issues of "free affective and cultural labor" ${ }^{27}$ are contested. Henry Jenkins, Sam Ford, and Joshua Green refer to this kind of labor as the "labor of love" because the work of online literary magazine editors enables them to "share [their work] with a larger audience," to have "pride in their accomplishments" and satisfy their "desire for dialogue." 28 Jenkins, Ford, and Green's argument is justified by experiences of editors such as Tammy Ho, co-founder of Cha. Answering a question about her aims and expectations in setting up the digital literary magazine, Ho replies that she and her co-founder "wanted to provide a platform for Hong Kong writers to showcase their work to a wider readership and also to encourage the exchange of literary work between Hong Kong and the rest of the world." ${ }^{29}$ Like Ho and her team at Cha, Eric Abrahamsen and his colleagues at the Paper Republic are similarly optimistic because of the positive reception and recognition of their literary magazines. As Abrahamsen puts it,

I think the two most telling kind of responses we've gotten are: a) translators of Chinese literature in other languages wanting to set up equivalent sites ..., and promoters of other countries' literature setting up sites like Paper Republic to promote those literatures. ${ }^{30}$

Despite their positive relationship to their digital labor, the affective and cultural labor of editors such as Ho and Abrahamsen expend on their work is still contested because of their unpaid nature.

Christian Fuchs, for example, critiques the defense of such unpaid nature of digital labor with affective and cultural rewards (the satisfaction of the user's "social and communicative needs and desires" of partaking in digital activities, the realization of "social, intellectual, and 
cultural worth," the appreciation from other users and institutions).$^{31}$ According to Fuchs, if "exploitation does not feel like exploitation, then this does not mean that it does not exist. It is exploitation even if users like it." 32 Fuchs regards unwaged digital labor as a form of exploitation despite the affective and cultural rewards because he tends to see the rewards in economic terms from a traditional Marxist perspective by equating rewards to monetary wages only. ${ }^{33}$

I see two problems with Fuchs's approach to rewards for digital labor. First, capital exists in forms beyond the economic capital, as Bourdieu outlines in his model of field, habitus, and capital. Second, affective and cultural rewards such as satisfaction and altruism do not have a place in Bourdieu's framework because he assumes that all agents in the literary field only have one purpose, and it is to accumulate capital. The affective and cultural rewards subject to exploitation to Fuchs hence can be interpreted in terms of symbolic capital and cultural capital in a Bourdieusian sense. Bourdieu calls such implicit rule of accumulating non-economic rewards and symbolic capital in the field of literary production, which will eventually be converted into economic capital, misrecognition: "Symbolic capital' is to be understood as economic or political capital that is disavowed, misrecognized and thereby recognized, hence legitimate, a 'credit' which, under certain conditions, and always in the long run, guarantees 'economic' profits." ${ }^{34}$ In other words, the free labor as an integral part of the magazine editors' digital labor does not generate rewards in the form of economic capital immediately. The non-economic rewards in the sense of symbolic capital, cultural capital, and social capital such as cultural prestige, literary knowledge, and social networks, however, bring about economic capital eventually such as literary prizes, employment opportunities, and new opportunities to participate in collaborative projects. As seen in the above explication on the relevance of Bourdieu's framework in relation to digital labor, free labor, digital archives, and online magazines, this framework offers a solution to the first problem of the free labor paradox regarding exploiting affective and cultural labor in unpaid terms. I therefore suggest using this framework to probe the transferral and traffic of capitals in the context of East Asian digital literary production.

The Bourdieusian model also explicates how canon is formed and shaped by various players and gatekeepers in the literary field. ${ }^{35}$ In the present context, the gatekeepers I focus on 
are the archivists of digital literary databases and editors of online literary magazines because they have the authority to decide which writer's works to translate and publish.

\section{The East Asian digital literary field}

Bourdieu's theory of field, capital, habitus, and doxa ${ }^{36}$ is appropriate to explicate the free labor paradox because such capitals as fame, literary networks, and literati status are transferrable into economic capital. As I explained earlier, the "free labor" is not actually unwaged. These flows of capital have to be situated back to where they take place (field). The archiving and publishing of digital literary products in the context of East Asian digital literatures (cultural production) give rise to the East Asian digital literary field. The agents in this field are compelled to follow the rules and conventions of the field (doxa) through offering their digital labor in the forms of digital archiving and online publishing. These agents acquaint themselves with such literary conventions through internalization, which become their "habitus," or a "ffeel for the game." 37 The agents partake in the digital literary production of the archives and magazines not only to produce cultural products (the archival materials and the magazine contents) but also to accumulate symbolic capital, cultural capital, and social capital, which will eventually earn them economic capital. These capitals, moreover, keep the agents in the field so that they can continue to engage themselves in literary production.

This traffic of capitals in the East Asian digital literary field overlaps with the world literary field, which also has its own sets of doxa, agents, and capitals. The canonization of East Asian literature is supposed to take place in such overlapped area through literary translation and circulation. This is because world literature is, according to Damrosch's definition, literature circulated in English translation. ${ }^{38}$ The agents in the East Asian digital literary field attempt to promote Hong Kong, Taiwan, and Mainland Chinese literatures through digital archives and online literary magazines. The agents promote their own literatures with their digital labor to a wider readership and such promotion acts as a mechanism to keep these agents in the East Asian digital literary field. Such labor, however, is vain in canonizing these literatures as world literatures because of the Eurocentrism, nation-centrism, English-translation-centrism, among other forms of -centrisms, exist as the doxa of the world literary canonizing mechanism. 
The agents, namely, the editors of Cha and the Paper Republic and the archivists of Hong Kong Literature Database, Hong Kong English Literature Database, and the Taiwan Literature Archives, admit unanimously that the production and the consumption of their local, national, and regional literatures remain an activity of the minorities. ${ }^{39}$ These editors and archivists also are all conservative about Hong Kong, Taiwan, and Mainland Chinese literatures as being part of the world literary canon because of their marginality. For instance, Nim-yan Wong, who manages the Hong Kong Literature Database, replies that she doesn't

think any work of Hong Kong literature has yet belonged to the canon of world literature, especially when even literature from the "Chinese proper," e.g. works by Mo Yan, are still striving for a place in the world literary "canon." 40

Kuei-fen Chiu, the archivist in charge of the digital timeline of Taiwan literary history of the Taiwan Literature Archives, echoes with Wong regarding the marginality of Taiwan literature: "I would not say that Taiwan literature belongs to the canon of world literature, given its marginal place in the world literary space." ${ }^{41}$ These convictions regarding the lack of place of East Asian digital literatures in the world literary canon exposes the exclusive notion of the "world" in world literature. These convictions, however, do not invalidate the digital labor involved in promoting the local, national, and regional literatures in these East Asian digital archives and magazines.

Despite such "-centrisms," it does not mean that the digital labor of these East Asian digital literary agents are vain in setting up and operating their archives or editing their literary magazines. This is because such labor, nevertheless, promotes the circulation of their own local, national, and regional literatures to readers encompassing students, teachers, critics, reviewers, writers, readers, funders, publishers, and researchers, who all play a role in the cultural production of the East Asian digital literary field. If these agents work together to engage in the circulation and cultural production of the East Asian literatures, the positionality of Hong Kong, Taiwan, and Mainland Chinese literatures has chances to slowly move toward the world literary canon. The digital labor that goes into the digital archives, moreover, establishes Hong Kong literature and Taiwan literature as academic disciplines by securing funding from their local 
governments, thereby justifying the significance of such labor in the working of the East Asian literary field.

\section{Hong Kong Chinese-language literature: Prof. Lu Wei-luan's Collection and the Hong Kong Literature Database}

The Hong Kong Literature Database is a database catalogued under the Prof. Lu Wei luan's Collection: Hong Kong Literature Archive. The Database and the Archive are an interrelated set of digital resources for researching on Hong Kong Chinese-language literature and its translation, dated literary magazines, newspaper supplements, and local literary criticism. The Database was initiated and launched with the joint effort of Prof. Lu Wei-luan (Xiao Si), a former professor of the Department of Chinese Language and Literature of the Chinese University of Hong Kong and Ms. Rita Wong-Poon Ming-chu, a former Deputy University Librarian. Nim-yan Wong, the newly appointed director (2016-) of Hong Kong Literature Research Centre is currently in charge of promoting the Database and the Archive. Wong highlights the poem from the Chinese monk, Master Hongyi, or Li Shutong (1880-1942) on the front page of the Archive, which encapsulates Lu's expectations for the project:

我到為種植, 我行花未開。豈無佳色在, 留待後人來。[I come here to plant/ Flowers have not blossomed when I am around/ Here are the washes of colours/ Awaiting latecomers to discover.] $]^{42}$

As Wong explains, Lu's intention of sharing "her printed collections and literature archival files with the public as well as people who study Hong Kong literature" took place "at a relatively early stage of database development, well before 'digital humanities' or 'big data' became widely discussed." ${ }^{43}$ The metaphor of planting the yet-to-blossom flowers in the poem hence alludes to Lu's vision of digitalizing her printed collection and leaving the product of her digital labor as legacies for "latecomers" to explore in the Database and the Archive.

When I asked if Wong was aware of any changes in academic discourse on Hong Kong literature since the Database and the Archive were launched in 2001 and 2005, respectively, 
Wong explicates the role of digital labor after 1997, when Hong Kong's sovereignty was transferred back to the People's Republic of China (PRC) from the United Kingdom:

Hong Kong literature is going through a stage of "post-postcoloniality," which is a stage evolving from dominance of theoretical concerns like "cultural identity," "gaze," "centre/periphery" to a more concrete and specific search on one's cultural character. A more diversified discourse involves a lot of data support which make studies of database not just an operational or technical issue. ${ }^{44}$

Lu's digital labor, in Wong's view, takes on an unintended significance in the post-postcolonial age since the time the Database was first initiated in 2000, which "does not limited [sic.] its aim as promoting any particular kind of cultural identity or scholarly canon." 45 Wong's response regarding the promotion of Hong Kong's "cultural identity" and the diversification of discourse through the Database and the Archive confirms the cultural significance of Lu's digital labor beyond their technical significance.

Although Wong asserts that digital labor devoted to Hong Kong literature "would definitely have a positive effect on [Hong Kong literature's] own position [in the world literary canon,]" such labor does "not necessarily move [the literature] one step closer to the canon" directly. ${ }^{46}$ Wong believes that "whether Hong Kong literature can position itself in the canon of world literature very much relates to the availability of translation. ${ }^{\prime 47}$ Recognizing the importance of translation in circulating Hong Kong literature among a wider readership through the translator's labor, ${ }^{48}$ Wong sees "the availability of searchable full texts and an English translation of them," 49 as the two principal concerns in the future preservation and promotion of the Database and the Archive. The case of the Database and the Archive shows that although the archivists do not consider Hong Kong literature as part of the world literary canon, the "funding and resources" invested in supporting the digital labor of Hong Kong literature still help Hong Kong literary studies establish itself as a scholarly field. ${ }^{50}$ The digital labor is hence not "free" due to such institutional support. The translator's labor also plays a part in slowly shifting the positionality of Hong Kong literature toward the world literary canon through making the literary translation available. 


\section{Hong Kong anglophone literature: The Hong Kong English Literature}

\section{Database}

Elaine Ho has promoted Hong Kong anglophone literature in the academic discourse since $2000 .{ }^{51}$ Her academic labor devoted to the advocacy for Hong Kong anglophone literature $^{52}$ is epitomized in the government-funded digital database, the Hong Kong English Literature Database (2010-). She stipulates five objectives for her project: First, to generate a "primary corpus of titles of fictional literature on Hong Kong;" second, to "categorize genres titles of fictional literature on Hong Kong;" third, to "provide summary information on the content of each title listed;" fourth, to "create a platform where this literature [...] can be introduced to and disseminated among a wider local and global readership;" and lastly, to enhance the efficiency of "readers outside Hong Kong who are looking for information" or to "help save valuable research time" of local scholars who can access the library collection of the University of Hong Kong. ${ }^{53}$ Among these objectives, the first one on generating a primary corpus of Hong Kong anglophone literature is the most essential because the objective outlines the originality and limits the scope of Ho's project as a government-funded one.

Ho's case shows that maintaining the product of digital labor is a continuous and laborintensive project. This is evident in the ongoing effort Ho puts in the Database even she has retired from her professorship in the School of English. Ho reveals her situation by replying to my question about her self-evaluation of her digital labor devoted to the Database:

Readers can contact the Chief Editor (me) via the database or directly through my HKU email address. So far, I have received about 50 emails, mostly requests for information and a couple of complaints from people about why their work or the work of their friend(s) was not included. The database is periodically updated with newer entries (not newer works) but my perception is that the basic work to establish a primary corpus is complete. $^{54}$

The continuous and labor-intensive nature of maintaining the Database is seen in Ho's receipt of "about 50 emails" about information queries and criticism on her selection of the literary works in the site. Ho's Database as a "primary corpus" of Hong Kong anglophone literature also exposes the Anglocentric weakness of the notion of world literature: "In the case of Moretti or 
Damrosch, the premium put on translation is, not always acknowledged, translation into English — which is, of course, ironical." 55 The irony here points directly at the contradiction between the multilingualism of the world and the Anglocentrism of the "world" in world literature. When I asked if Ho conceives Hong Kong literature as part of the world literary canon, Ho says that "if [Hong Kong anglophone literature continues to be written in English, it will never be [labelled 'Chinese' literature]. ${ }^{, 56}$ That implies that the nation-centric doxa of the world literary field excludes Hong Kong anglophone literature not only because Hong Kong is not a nation but also because as a Special Administrative Region within the PRC with bilingualism (English and Chinese), its literature is not only written in the official language of the nation (Chinese). Hence the Hong Kong anglophone literature cannot gain premium to enter the world literary field through the medium of translation.

\section{Taiwan literature: The Taiwan Literature Archives}

Kuei-fen Chiu, who constructs the digital timeline of Taiwan literary history (16521987), ${ }^{57}$ shares some data to showcase the international reception of the Archives, which reveals the significance of her digital labor in 'creat[ing] 'room' for Taiwan literature in the world literary space of the internet age." ${ }^{, 58}$ For example, the Yang $M u$ archive ${ }^{59}$ featuring the eponymous poet (1940-) has hosted visitors from Taiwan $(30,909)$, the United States $(2,780)$, Hong Kong (1,428), Ukraine (1,055), Singapore (575), Russia (357), Malaysia (262), Germany (215), France (180), and Canada (162) with a monthly browse of 1,348 visitors in June $2016 .^{60}$ These data show that although Taiwan literature still occupies a "marginal place in the world literary space," Chiu's digital labor devoted to the Archives, with the institutional support from the National Museum of Taiwan Literature, is already gradually shifting the positionality of Taiwan literature toward the world literary field by engaging more readers, teachers, and researchers in the "discourse." 61

What differentiates Chiu from other laborers in this chapter is her vision and optimism of the potential of Taiwan literature in contributing to world literature, which underscores the significance of the role of digital labor in the world literary field. Distinct from the current Anglocentric worlding mechanism, Chiu believes that Taiwan literature can make important 
contribution to the "world-forming" mechanism in the future development of world literary field:

we think of the "world" of "world literature" as "world-forming" (a la Pheng Cheah) or "world-to-come" (in the Derridean sense). [...] once we begin to think of Taiwan literature as world literature, the focus shifts from the debate on "Chineseness" (how "Chinese" is Taiwan literature) to "worldliness." A new framework of conceptualizing Taiwan literature begins to emerge. ${ }^{62}$

In other words, digital labor, as in the case of the Archives, plays a pivotal role in the shaping of world literature by offering a timeline of literary history of Taiwan literature to critics to develop new frameworks in moving Taiwan literature away from the East Asian cultural sphere (sinophere) to the world literary field.

\section{Asian literature: Cha: An Asian Literary Journal}

The ways in which online literary magazines embody a return of the free labor paradox are epitomized by the case of Cha co-founded by Tammy Ho. In 2007, when Ho co-founded the magazine, her team wanted to "provide a platform for Hong Kong writers to showcase their work to a wider readership and also to encourage the exchange of literary work between Hong Kong and the rest of the world. ${ }^{\prime 63}$ Ho highlights the role of English as a means to connect Hong Kong to the world in what Wong calls the "post-postcolonial” age. ${ }^{64}$ "[W]e set up Cha in 2007, ten years after the handover, may also be viewed as an attempt to ensure the continued use of English in cultural and literary expression in the city." ${ }^{65}$ In choosing English as a medium, Ho aligns with Elaine Ho, Nim-yan Wong, and Kuei-fen Chiu who look up to international recognition of Hong Kong and Taiwan literatures even though the city or the island has an ambivalent relation to the nationhood of China. Contrasting with Chiu's response, Ho, like other Hong Kong digital archivists, prefers not to measure "Hong Kong literature against world literature." ${ }^{66}$ She stresses on the problematic notion of the world literary canon, which implies the dated notion of granting permits to national literatures into the canon in our de-nationalized age.

With new and returning contributors, Cha has established a virtual community of Asian literatures, ${ }^{67}$ countering the Anglocentrism of the canon. Despite the free nature of the labor, the 
collaborative work of the editors is rewarded with social capital (literary networks) and symbolic capital (literary recognition). ${ }^{68}$ Ho's attempt to preserve Cha in catalogues of tertiary libraries, moreover, is an act of historicizing the under-acknowledged histories of digital labor in the past and the present.

\section{Chinese literature: The Paper Republic}

As I mentioned previously, due to various -centrisms, the availability of translation is not the only critical factor that determines if a national literature can enter the canon. The Paper Republic co-founded and run by translators of Chinese fiction based in Mainland China presents a different case from the rest. Eric Abrahamsen, an editor and a translator of the site, states that the primary objective of the site was to "create a translators' collective," but it has now become raising "awareness of Chinese fiction abroad, and to facilitate a growing number of translations and publications of Chinese books into English." 69 The Paper Republic is a site mainly publishing the translation of Mainland Chinese literature, with a small number of renditions on Hong Kong literature, Taiwan literature, and Chinese diasporic literature. The site, therefore, exemplifies a digital product in the East Asian digital literary field and being closest to entering the world literary field in compared with the others. This is because the national literature on the site embodies the nationhood as a doxa required for entering the world literary field. Mainland Chinese literature, however, still faces other major problems apart from translation in the process of canonization, especially in regard to state censorship ${ }^{70}$ and the Anglocentric mechanism of international reception. ${ }^{71}$

A main objective of the site is to promote Chinese literature, which is still "waiting for real recognition."72 Abrahamsen's digital labor, therefore, contributes to shifting the positionality of Chinese literature in the world literary field by circulating literary works of overlooked Chinese writers. Abrahamsen points out, “[d] espite Mo Yan’s Nobel [P]rize win,” Western readers and publishers are still more comfortable with Chinese books "written in English by expat Chinese writers," by "dissident Chinese writers," or by "Western writers in China."73 Western readers, especially, fail to develop "their own relationships with [the writers whose works are translated and published]" because their "relationships are still with individual books." 74 The digital labor that goes into setting up the Paper Republic and running its affiliated 
magazine, Pathlight (2016-), ${ }^{75}$ is hence modest but essential in helping Chinese literature, especially that from Mainland China, to overcome the barriers of the Anglocentrism and state censorship that prevent such literature from approaching the world literary field.

\section{Conclusion}

The archives and the online magazines in this chapter embody the significance of digital labor in the East Asian digital literary field. The agents in the field use their labor to promote local literary production by translating, publishing, and circulating Hong Kong, Taiwan, and Mainland Chinese literatures. Four out of five of these archivists and editors whom I interviewed are women of Chinese ethnicity. If we also consider the contributor Prof. Lu Wei-luan (Xiao Si) and the librarian Ms. Rita Wong-Poon Ming-chu assisting the launch of the Prof. Lu Wei-luan's Collection and the Hong Kong Literature Database, six out of seven laborers are women, with Ms. Wong especially subject to what Madeleine Monson-Rosen examines in this volume as the erasure of women's digital labor. This chapter echoes this collection's main argument that textuality and digital labor, despite genders and skin colors of the laborers, are embodied. These archives and magazines, however, refract the unequal canonizing mechanism of world literature through accentuating the problems of translation, "-centrisms," and the nation-centered and Anglocentric notion of the "world" in the world literary field. Despite these difficulties for such minor literatures to become internationally recognized, digital labor nevertheless facilitates these literatures to move toward the world literary field and helps proclaiming each of these literatures as an autonomous scholarly field with their own literary significance overlapping with the world literary field.

\footnotetext{
${ }^{1}$ I am grateful to Shawna Ross, Andrew Pilsch, Eric Abrahamsen, Kuei-fen Chiu, Sin-piu Fan, Elaine Yee-lin Ho, Tammy Lai-ming Ho, Nim-yan Wong, and Michael Ka-chi Cheuk for their help in enabling the writing of this chapter.

${ }^{2}$ David Damrosch, "World Literature in a Postliterary Age," Modern Language Quarterly 74.2 (2013): 151-70.

${ }^{3}$ Franco Moretti, “Conjectures on World Literature,” New Left Review 1.1 (2000): 54-68.

${ }^{4}$ HK Literature Database (2000-2018), http://hklitpub.lib.cuhk.edu.hk/index_eng.jsp.

${ }^{5}$ Prof. Lu Wei-luan's Collection: Hong Kong Literature Archive (2005-2007), http://hklitpub.lib.cuhk.edu.hk/lovf.

${ }^{6}$ Hong Kong English Literature Database (2010-), www.hongkong-english-lit.net.

${ }^{7}$ The Taiwan Literature Archives (2014-), http://twlit.blogspot.hk.
} 
${ }^{8}$ Cha: An Asian Literary Journal (2007-2019), http://asiancha.com.

${ }_{9}^{9}$ Paper Republic: Chinese Literature in Translation (2007-), http://paper-republic.org/.

${ }^{10}$ Shu-mei Shih, "Global Literature and the Technologies of Recognition," PMLA 119.1 (2004): 16-30.

${ }^{11}$ Damrosch argues for world literature can be defined as "a mode of circulation and of reading." Damrosch, "World Literature," 5.

${ }^{12}$ David Damrosch outlines three definitions of world literature. First, it is "an elliptical refraction of national literatures." Second, it refers to "writing that gains in translation." Third, it "is a mode of reading: a form of detached engagement with worlds beyond our own place and time" David Damrosch, "World Enough and Time," in What Is World Literature? (Princeton, NJ: Princeton University Press, 2003), 281-303, 282.

${ }^{13}$ Pascale Casanova, The World Republic of Letters (Cambridge, MA: Harvard University Press, 2007), 103, 193.

${ }^{14}$ Another way to account for such nationalistic criterion of defining the eligibility of becoming world literature is that existing critics are still adopting the nineteenth-century notion of national literature as a unit of comparison, originated from the early years of comparative literature as a discipline, which shapes world literature today. See Ackbar Abbas, "Hong Kong," in The Cinema of Small Nations, eds. Mette Hjort and Duncan J. Petrie (Edinburgh: Edinburgh University Press, 2007), 113-26, 117.

${ }^{15}$ Sun Sun Lim and Cheryll Ruth Soriano, eds., Asian Perspectives on Digital Culture: Emerging Phenomena, Enduring Concepts (New York: Routledge, 2016).

16 "Digital Humanities Asia: Harnessing Digital Technologies to Advance the Study of the Non-Western World," International conference April 26-29, 2018, Stanford University.

${ }^{17}$ Lim and Soriano, Asian Perspectives, 5.

${ }^{18}$ Lawrence Venuti, The Scandals of Translation: Towards an Ethics of Difference (New York: Routledge, 1998), 170.

${ }^{19}$ Julie Thompson Klein, 2015. Interdisciplining Digital Humanities: Boundary Work in an Emerging Field (Ann Arbor: University of Michigan Press, 2015), 34.

${ }^{20}$ Maurizio Lazzarato, "Immaterial Labor," in Radical Thought in Italy: A Potential Politics, eds. Paolo Virno and Michael Hardt (Minnesota: University of Minnesota Press, 2006), 133-47, 133.

${ }^{21}$ Tiziana Terranova, "Free Labor: Producing Culture for the Digital Economy," Social Text 18.2 (2000): 33-58, 41, 48

${ }^{22}$ Ibid., 133.

${ }^{23}$ Ho, Elaine Yee-lin, interview with the author via questionnaire, June 4, 2017.

${ }^{24}$ Chiu, Kuei-fen, interview with the author via questionnaire, June 10, 2017.

${ }^{25}$ Terranova, "Free Labor," 46.

${ }^{26}$ Ibid.

${ }^{27}$ Ibid.

${ }^{28}$ Henry Jenkins, Sam Ford, and Joshua Green, Spreadable Media: Creating Value and Meaning in a Networked Culture (New York and London: New York University Press, 2013), 61, 59.

${ }^{29}$ Tammy Lai-ming Ho, interview with the author via questionnaire, June 12, 2017. 
${ }^{30}$ Eric Abrahamsen, interview with the author via questionnaire, June 10, 2017.

${ }^{31}$ Christian Fuchs, "Henry Jenkins and Digital Labor," in Social Media: A Critical Introduction (Los Angeles: Sage, 2014), 63-64.

${ }^{32}$ Ibid.

${ }^{33}$ Tony Cutler, Barry Hindess, Athar Hussain, and Paul Q. Hirst, eds., "Value, Exploitation, and Profit," in Marx's Capital and Capitalism Today (London: Routledge, 2012), 11-50, 31.

${ }^{34}$ Pierre Bourdieu, "The Production of Belief: Contribution to an Economy of Symbolic Goods," in The Field of Cultural Production: Essays on Art and Literature, ed. Randal Johnson (Cambridge, MA: Polity, 1993), 74-111, 55, emphasis added.

${ }^{35}$ The Bourdieusian term for canonization is "consecration." See Pierre Bourdieu, The Field of Cultural Production, ed. Randal Johnson (Cambridge, MA: Polity Press, 1993), 106-7, 122-3. See also Katherine Bode and Tara Murphy, "Methods and Canons: An Interdisciplinary Excursion," in Advancing Digital Humanities: Research, Methods, Theories, eds. Paul Arthur and Katherine Bode (Basingstoke: Palgrave Macmillan), 17-93. Bode and Murphy's study is a data-based analysis in the Australian literary field, specifically looking at the site, AustLit, 2000, www.austlit.edu.au/

${ }^{36}$ Pierre Bourdieu, "The Field of Cultural Production, or: the Economic World Reversed," Poetics 12.4-5 (1983):

311-56; Pierre Bourdieu, The Rules of Art: Genesis and Structure of the Literary Field, trans. Susan Emanuel (Stanford: Stanford University Press, 1996).

${ }^{37}$ Bourdieu, The Field of Culture Production, 5.

${ }^{38}$ Damrosch "World Literature," 5.

${ }^{39}$ Ho, Abrahamsen, Wong, and Chiu, interviews with the author via questionnaire.

${ }^{40}$ Nim-yan Wong, interview with the author via questionnaire, June 11, 2017.

${ }^{41}$ Chiu, interview.

${ }^{42}$ Nim-yan Wong, interview with the author via questionnaire, June 11, 2017.

${ }^{43}$ Ibid.

${ }^{44}$ Ibid.

${ }^{45}$ Ibid.

${ }^{46}$ Ibid.

${ }^{47}$ Ibid.

${ }^{48}$ Lawrence Venuti, “Canon,” in The Translator's Invisibility: A History of Translation (London: Routledge, 2008), 35-82.

${ }^{49}$ Wong, interview.

${ }^{50}$ Ibid.

${ }^{51}$ Elaine Yee-lin Ho, “Connecting Cultures: Hong Kong Literature in English, the 1950s.” New Zealand Journal of Asian Studies 5.2 (2000): 5-25. 
${ }^{52}$ For more on the recent development of academic labor studies, see Vincent B. Leitch, "Work Theory" Critical Inquiry 31.2 (2005): 286-301; Marc Bousquet, How the University Works: Higher Education and the Low-Wage Nation (New York: New York University P, 2008).

${ }^{53} \mathrm{Ho}$, interview, emphasis original.

${ }^{54}$ Ibid.

${ }^{55}$ Ibid.

${ }^{56}$ Ibid.

57 “Timeline," The Taiwan Literature Archives, 2014, http://twlit.blogspot.hk.

${ }^{58}$ Chiu, interview.

59 "Yang Mu," The Taiwan Literature Archives, 2014, http://yangmu.com.

${ }^{60}$ Chiu, interview.

${ }^{61}$ Ibid. See also Melissa Dinsman et al., also in this collection.

${ }^{62}$ Chiu, interview.

${ }^{63} \mathrm{Ho}$, interview.

${ }^{64}$ Wong, interview.

${ }^{65} \mathrm{Ho}$, interview.

${ }^{66}$ Ibid.

${ }^{67}$ Cha occasionally publishes special issues, including “The China Issue,” no. 14 (July 2011), "The Ancient Asia Issue," no. 21 (December 2013), “The Writing Japan” issue, no. 36 (June 2017), and “The Writing Hong Kong” issue, no. 37 (December 2017).

${ }^{68}$ For a list of awards received by $C h a$, see www.asiancha.com/content/blogcategory/0/46.

${ }^{69}$ Abrahamsen, interview.

${ }^{70}$ See Michel Hockx, Internet literature in China (New York: Columbia University Press, 2015). Hockx argues, "The existence of censorship per se can never be a reason to dismiss any literature, nor can it ever be argued that only literary fields with weak or no censorship institutions are worth studying” (x).

${ }^{71}$ Shu-mei Shih theorizes the international (Western) mechanism of receiving Third-World literature as "the politics of recognition." See Shih, "Global Literature."

${ }^{72}$ Abrahamsen, interview.

${ }^{73}$ Ibid.

${ }^{74}$ Ibid.

${ }^{75}$ Pathlight, 2016-, http://paper-republic.org/pubs/pathlight. 